\title{
THE FATE OF $S$. TYPHI IN BLOOD CLOT IN RELATION TO THE PROBLEM OF ISOLATION
}

\author{
BY \\ KENNETH C. WATSON \\ From the Natal Provincial Administration, Grey's Hospital, Pietermaritzburg, South Africa
}

(RECEIVED FOR PUBLICATION JUNE 9, 1954)

Bile salt broth containing streptokinase (100 units $/ \mathrm{ml}$.) has in our experience proved superior to ordinary bile broth as a culture medium for the isolation of $S$. typhi from blood clot (Thomas, Watson, and Hewstone, 1954). This superiority refers both to the total number of positive isolations and to the shorter duration of incubation required. In a series of 18 cases (16 typhoid and two paratyphoid A), where one half of each clot was incubated in $15 \mathrm{ml}$. of streptokinase broth and the other half in $15 \mathrm{ml}$. of bile broth alone, six of the latter were negative after 14 days' incubation, but the corresponding halves in streptokinase broth produced a growth of $S$. typhi.

In view of the failure of these six half-clots to produce a positive result a study was undertaken of the fate of $S$. typhi in blood clot.

\section{Preparation of Artificially Infected Clots}

Serial tenfold dilutions were prepared from an overnight digest broth culture of a freshly isolated strain of $S$. typhi in $0.85 \%$ sterile saline. Plate count estimations were performed, and in this way a suspension containing approximately $\mathbf{4 0}$ viable organisms per $\mathrm{ml}$. was prepared. One-millilitre volumes were placed in 50 sterile 3 in. by $\frac{1}{2}$ in. tubes and $4 \mathrm{ml}$. of blood from a donor added to each. The bloodbacterium suspension was well mixed and the blood

TABLE I

ISOLATION OF $S$. TYPHI FROM CLOT IN STREPTOKINASE AND BILE BROTHS

\begin{tabular}{c|c|c|c|c}
\hline \multirow{2}{*}{ Day } & \multicolumn{2}{|c|}{ Streptokinase Bile Broth } & \multicolumn{2}{c}{ Bile Broth Alone } \\
\cline { 2 - 5 } \cline { 3 - 5 } & Positive & Negative & Positive & Negative \\
\hline 1 & 43 & 7 & 22 & 28 \\
2 & 50 & Nil & 22 & 28 \\
3 & - & - & 24 & 26 \\
4 & - & - & 30 & 20 \\
8 & - & - & 32 & 18 \\
9 & - & - & 34 & 16 \\
14 & - & & & 16 \\
\hline
\end{tabular}

allowed to clot. After two hours at room temperature the separated serum was removed and each clot $\stackrel{\circ}{5}$ bisected using sterile Petri plates and microscope $\overrightarrow{ }$ slides as already described (Thomas et al., 1954). T) One-half of each clot was then incubated in $15 \mathrm{mi}$. 을 of streptokinase bile broth and the other half in $15 \mathrm{ml}$. of bile broth in universal containers. Subcultures were plated daily on to Wilson and Blair's medium $\overrightarrow{0}$ for $\mathbf{1 4}$ days. Results are detailed in Table $\mathrm{I}$.

Table I shows that $16(32 \%)$ of the half-clots in bile broth alone were negative after 14 days. All those in streptokinase broth gave a positive result after two days' incubation. Examination of the culture bottles after 14 days showed that $\frac{\mathscr{Q}}{\square}$ $64 \%$ of the bile broth series still contained large $\varrho$ volumes of formed clot. In the streptokinase broth $\overrightarrow{\overrightarrow{0}}$ series clot lysis was complete in $\mathbf{4 8}$ hours in each 3 case. Of the 16 negative cultures all contained formed clot.

At the end of the 14-day incubation period each 옹 clot from the 16 negative containers was trans- ferred to a fresh container with $15 \mathrm{ml}$. of streptokinase broth. Lysis occurred quickly in each case, $\delta$ in 18 to 24 hours, but in spite of this no further positive isolations were obtained when subcultures 0 were plated daily for a further 14 days. The original organisms in fact appeared to have died off. Since the corresponding halves of each of these clots gave positive isolations in streptokinase ? broth it is not likely that the halves cultured in N bile broth for 14 days were initially sterile.

\section{Effect of Storage of Infected Clots at $4^{\circ} \mathrm{C}$. and at $37^{\circ} \mathrm{C}$.}

Twenty-four artificially infected clots were prepared $\stackrel{?}{+}$ and bisected as described. Each half contained approximately 25 viable organisms. One-half of each $\frac{\vec{D}}{\mathrm{D}}$ was incubated immediately in $15 \mathrm{ml}$. of streptokinase $\stackrel{\odot}{\rho}$ broth. The remaining half-clots were divided into $\mathbb{Q}$ four groups, two being stored at $4^{\circ} \mathrm{C}$. for seven and $\frac{\sigma}{\sigma}$ 14 days respectively and two at $37^{\circ} \mathrm{C}$. for similar 
periods. Each half-clot was then added to $15 \mathrm{ml}$. of streptokinase broth and incubated at $37^{\circ} \mathrm{C}$. Subcultures were plated daily as before. Results are shown in Table II.

TABLE II

EFFECT OF STORAGE OF INFECTED CLOTS AT $4^{\circ} \mathrm{C}$. AND $37^{\circ} \mathrm{C}$.

\begin{tabular}{|c|c|c|c|c|c|c|c|}
\hline \multicolumn{4}{|c|}{$4^{\circ} \mathrm{C}}$. & \multicolumn{4}{|c|}{$37^{\circ} \mathrm{C}$. } \\
\hline \multicolumn{2}{|c|}{$\begin{array}{l}\text { Clot No. for } \\
7 \text { Days }\end{array}$} & \multicolumn{2}{|c|}{$\begin{array}{l}\text { Clot No. for } \\
14 \text { Days }\end{array}$} & \multicolumn{2}{|c|}{$\begin{array}{l}\text { Clot No. for } \\
7 \text { Days }\end{array}$} & \multicolumn{2}{|c|}{$\begin{array}{l}\text { Clot No. for } \\
14 \text { Days }\end{array}$} \\
\hline $\begin{array}{l}1 \\
2 \\
3 \\
4 \\
5 \\
6\end{array}$ & $\begin{array}{l}+1 \\
+1 \\
+1 \\
+1 \\
+1 \\
+1\end{array}$ & $\begin{array}{r}7 \\
8 \\
9 \\
10 \\
11 \\
12\end{array}$ & $\begin{array}{l}+1 \\
+1 \\
+1 \\
+1 \\
+1 \\
+1\end{array}$ & $\begin{array}{l}13 \\
14 \\
15 \\
16 \\
17 \\
18\end{array}$ & $\begin{array}{r}+2 \\
+3 \\
+4 \\
-14 \\
-14 \\
+4\end{array}$ & $\begin{array}{l}19 \\
20 \\
21 \\
22 \\
23 \\
24\end{array}$ & $\begin{array}{r}-14 \\
-14 \\
-14 \\
-14 \\
+2 \\
-14\end{array}$ \\
\hline
\end{tabular}

$+=$ Positive isolation. $-=$ Negative result. Figures after + and - signs = number of days' incubation.

The second series of 24 half-clots resulted in only four positive isolations after subculturing daily for 14 days. The corresponding halves incubated immediately in streptokinase broth all gave a positive result after two days' incubation.

The above results appear to support the contention that viable organisms may be killed off in the clot during the preliminary phase of incubation of either the clot alone or clot in bile broth. The complete lysis occurring in streptokinase broth would liberate organisms trapped in the fibrin meshwork and allow them to proliferate if still viable.

It appeared that one or both of two factors might be responsible for these findings: (1) sufficient natural antibody and complement might be adsorbed on the clot meshwork to produce a bactericidal action; or (2) phagocytic mechanisms in the clot might produce a similar result.

The following methods were adopted to study the problem more fully.

\section{Incubation of S. typhi in Citrated Blood after Removal of Plasma}

Five ml. volumes of blood from a donor were added to $1 \mathrm{ml}$. volumes of $S$. typhi suspension containing approximately 60 viable organisms, and $0.5 \mathrm{ml}$. volumes of sterile $3.8 \%$ sodium citrate in sterile centrifuge tubes. The tubes were spun at 3,000 revs.

TABLE III

ISOLATION OF $S$. TYPHI FROM INFECTED CELL SUSPENSIONS

\begin{tabular}{c|c}
\hline No. of Cultures & No. of Positive Isolations \\
\hline 16 & 12 (after 1 day) \\
16 (after 2 days)
\end{tabular}

for 30 minutes and the plasma removed. The infected cells were then incubated at $37^{\circ} \mathrm{C}$. for 14 days and then added as before to $15 \mathrm{ml}$. of streptokinase broth. Subcultures were plated daily. Results are shown in Table III.

All 16 gave a positive isolation after two days' incubation. In this case all plasma had been removed so that the effect of antibody and complement could be ruled out, though any phagocytic action might still be expected to play a part.

\section{Incubation of S. typhi in Human Fibrin Clot}

Four-ml. volumes of a $1 \%$ solution of human fibrinogen were added to $1-\mathrm{ml}$. volumes of $S$. typhi saline suspension containing approximately 60 viable organisms in sterile 5 in. by $\frac{5}{8}$ in. tubes. A drop of commercial thrombin was added to each, and after clotting the tubes were incubated at $37^{\circ} \mathrm{C}$. for 14 days before being added to streptokinase broth as described. Results of subculture are detailed in Table IV.

TABLE IV

ISOLATION OF $S$. TYPHI FROM INFECTED HUMAN FIBRIN

\begin{tabular}{c|c}
\hline No. of Cultures & No. of Positive Isolations \\
\hline 30 & $\begin{array}{l}25 \text { (after } 1 \text { day) } \\
30 \text { (after } 2 \text { days) }\end{array}$
\end{tabular}

Again positive isolations were obtained from $100 \%$ of the infected clots in spite of the preliminary period of incubation at $37^{\circ} \mathrm{C}$.

\section{Discussion}

Felix (1924), Soman (1932), and Compton and Said (1933) all stress the need for removal of the separated serum before culturing the residual clot. With regard to the isolation of $S$. typhi from blood clot, Felix states: "The culture of $B$. typhosus or $B$. paratyphosus $A$ and $B$ from coagulum bile was hardly ever unsuccessful when it was successful from blood bile. The contrary, however, was often the case." He considers that this is due to the removal of bacteriolytic factors when the serum is discarded. We have already shown that the results of clot culture using streptokinase broth are considerably better than those of the routine culture of whole blood using $35 \mathrm{ml}$. of bile broth for the latter, and that this is due to the presence of bactericidal serum factors in sufficient concentration to produce a bacteriolytic action (Watson, 1954).

No mention appears to have been made, however, of the effect that serum adsorbed on the clot meshwork may have on organisms contained in the clot. The observations presented above 
would indicate that these may be of considerable importance. Particularly will this apply where there is little or no lysis of the clot taking place, as in bile broth alone, since there will be no opportunity for dilution of the serum by the volume of medium. It also appears that the bactericidal action of such serum is not limited to the period when serum is present in the clot before retraction occurs, since infected clots added to streptokinase broth immediately retraction was complete all gave positive results. A certain amount of killing is to be expected then, but does not appear to be sufficient to cause complete sterility in the case of an inoculum of 40 to 60 organisms.

The bactericidal action observed after seven days' storage at $37^{\circ} \mathrm{C}$. was less than that after 14 days. Mackie and Finkelstein (1932) have shown that the bactericidal action of normal serum against Gram-negative organisms is dependent on the presence of antibody and complement. However, the greater number of negative results after 14 days than after seven suggests that other factors may be responsible since complement tends to disappear in about four days at $37^{\circ} \mathrm{C}$. Wright (1942) has been able to demonstrate an increase in the bactericidal power of blood following the addition of organisms to it in vitro, and attributes this to the release of factors from the leucocytes. Such factors, and the naturally occurring bactericidins not dependent on the action of complement, may be responsible for the killing observed between seven and 14 days at $37^{\circ} \mathrm{C}$.
Whether or not a bactericidal effect will occur in the case of organisms trapped in blood clot $\stackrel{5}{5}$ will depend on a number of factors, including $(a)+\frac{}{0}$ the volume of adsorbed serum, which in turn is 을 dependent on the degree of clot retraction, $(b)$ the $\frac{\bar{\rho}}{\bar{\sigma}}$ strength of any bactericidal factors present, and $\stackrel{\Phi}{\Omega}$ (c) the particular strain of $S$. typhi and the number of organisms.

It would seem essential in clot culture techniques $\vec{\circ}$ in typhoid fever to bring about rapid lysis of the $\overrightarrow{\vec{\omega}}$ clot in addition to removing as much of the ex- $\stackrel{\omega}{\rho}$ pressed serum as possible.

\section{Summary}

Incubation of blood clot infected with $S$. typhi 을 may result in killing the organisms if quick lysis does not occur. Killing was observed in clots 7 stored at $37^{\circ} \mathrm{C}$. but not at $4^{\circ} \mathrm{C}$. Evidence is $\frac{\mathbb{0}}{0}$ presented that serum factors may be adsorbed on the clot meshwork in sufficient amounts to produce a bactericidal effect.

I am indebted to Dr. J. C. Thomas, Provincial Pathologist, Natal Provincial Administration, for his continued interest.

\section{REFERENCES}

Compton, A., and Said, I. A. (1933). Lancet, 2, 580.

Felix, A. (1924). J. Immunol., 9, 115 .

Mackie, T. J., and Finkelstein, M. H. (1932). J. Hyg., 32, 1.

Mackie, T. J., and Finkelstein, M. H. (1932).

Thomas, J. C., Watson, K. C., and Hewstone, A. S. (1954). Journal of Clinical Pathology, $7,50$.

Watson, K. C. (1954). Ibid., 7, 305.

Wright, A. E. (1942). Proc. roy. Soc. Med., 35, 161. 